\title{
Soil Microbial Biomass Dynamics and Net Nitrogen Mineralization in Northern Hardwood Ecosystems
}

\author{
William E. Holmes and Donald R. Zak*
}

\begin{abstract}
Soil temperature, water potential, and substrate (C) availability are the primary constraints on microbial activity within soil and display substantial seasonal variation within northern deciduous forests. Following autumn litterfall, soil $\mathbf{C}$ availability is relatively high, and $\mathbf{N}$ should be assimilated by soil microorganisms to maintain or form new biomass. Conversely, $\mathbf{N}$ should be mineralized from microbial biomass during midsummer when $\mathrm{C}$ availability is relatively low and soil temperatures are high. Because $\mathbf{N}$ availability is directly controlled by microbial activity, we hypothesized that microbial biomass and net $\mathbf{N}$ mineralization are inversely related on a seasonal basis. To test this hypothesis, we studied the temporal relationship between microbial biomass ( $\mathrm{C}$ and $\mathrm{N}$ ) and rates of net $\mathrm{N}$ mineralization in two different northern hardwood ecosystems, one dominated by sugar maple (Acer saccharum Marsh.) and basswood (Tilia americana L.) and the other by sugar maple and red oak (Quercus rubra $\mathbf{L}$.). In situ buried bags were used to estimate net $\mathbf{N}$ mineralization and nitrification at monthly intervals for $1 \mathrm{yr}$. Microbial $\mathrm{C}$ and $\mathrm{N}$ contents of the incubated soil were determined using the chloroform fumigation-incubation method. Net $\mathbf{N}$ mineralization displayed marked seasonal variability, ranging from 35 to $115 \mathrm{mg} \mathrm{N} \mathrm{m}^{-2} \mathrm{~d}^{-1}$ during the growing season. In contrast, microbial biomass $\mathrm{C}$ and $\mathrm{N}$ were relatively constant throughout the year, averaging $112 \mathrm{~g} \mathrm{C} \mathrm{m}^{-2}$ and $17 \mathrm{~g} \mathrm{~N} \mathrm{~m}^{-2}$. Neither microbial biomass ( $C$ or $N$ ) nor the change in microbial biomass between sampling dates were significantly inversely correlated with mean daily rates of net $\mathrm{N}$ mineralization. As such, our data do not support the idea that $\mathbf{N}$ availability is controlled by large seasonal fuctuations in soil microbial biomass. Rather, our results suggest that $N$ availability is primarily controlled by changes in the turnover rate of microbial biomass such that a relatively constant pool is maintained through time. In addition, mean annual rates of net $\mathbf{N}$ mineralization and nitrification did not differ significantly from those previously measured by others in the same stands, suggesting that annual rates may be relatively consistent in climatically similar years.
\end{abstract}

School of Natural Resources and Environment, Univ. of Michigan, 430 E. University Ave., Ann Arbor, MI 48109-1115. Received 25 Mar.1993. *Corresponding author.

Published in Soil Sci. Soc. Am. J. 58:238-243 (1994).
SoIl Microorganisms play an integral function in $\checkmark$ the cycling of $\mathrm{N}$ within terrestrial ecosystems. Temporal variation in rates of $\mathrm{N}$ transformations results from seasonal changes in factors controlling microbial activity, like soil temperature, water potential, and C availability. Several studies suggest that seasonal variation in microbial biomass corresponds to variation in soil water potential and substrate (i.e., C) availability (Clarholm and Rosswall, 1980; Singh et al., 1989; Srivastava, 1992). These factors vary widely during the growing season within northern temperate forests. Few studies, however, have investigated the seasonal variation of microbial biomass within these ecosystems (Groffman and Tiedje, 1989). As a consequence, it is uncertain whether microbial biomass varies or remains constant during the growing season.

Microbial activity within soil is thought to be most limited by $\mathrm{C}$ input from plant litter production (Smith and Paul, 1990). In deciduous forests, an autumnal pulse of $C$ occurs when aboveground and belowground litter fluxes reach seasonal peaks. Under conditions of increased substrate availability, microbial populations could increase, provided that soil temperature and water potential do not limit growth. Such a situation could occur following autumn litterfall in northern deciduous forests. During this period, microbial biomass should increase and rates of net $\mathrm{N}$ mineralization decline as $\mathrm{N}$ is assimilated to form new microbial biomass. Conversely, during midsummer when $C$ availability is relatively low, $N$ should be mineralized from microbial biomass as populations decline. We hypothesized that microbial biomass and net $\mathrm{N}$ mineralization are inversely related during the growing season.

\footnotetext{
Abbreviations: $K_{n}$, microbial biomass $\mathrm{N}$ correction factor; $\mathrm{C}_{\mathrm{f}}$ and $N_{f}$, flushes of $C$ and $N$ from fumigated samples, respectively; ANOVA, analysis of variance; LSD, Fisher's protected least significant difference; MSE, mean square error; $\mathrm{BC}$, microbial biomass $\mathrm{C}$; $\mathrm{OC}$, organic $\mathrm{C}$; $\mathrm{SD}$, standard deviation.
} 
We tested our hypothesis by comparing the seasonal variation of soil microbial biomass and $\mathrm{N}$ transformations in two different northern hardwood ecosystems that are widely distributed throughout northern Lower Michigan. Additionally, we compared annual rates of net $\mathrm{N}$ mineralization and nitrification to previously published estimates to examine the year-toyear variation of $\mathbf{N}$ dynamics.

\section{METHODS}

\section{Study Area}

We studied microbial biomass and $\mathrm{N}$ dynamics in the sugar maple-basswood/Osmorhiza and sugar maple-red oak/Maianthemum ecosystems. These ecosystems were classified using a multifactor approach that integrates landform, soil, and vegetation (Barnes et al., 1982, Pregitzer and Barnes, 1984); both occupy relatively large land areas in northern Lower Michigan. Within each ecosystem, two stands were selected from a pool of three previously studied stands (Zak and Pregitzer, 1990). Stands representative of the two ecosystems were located within the Manistee National Forest in northwestern Lower Michigan $\left(44^{\circ} 22^{\prime} \mathrm{N}, 85^{\circ} 30^{\prime} \mathrm{W}\right.$; Zak and Pregitzer 1990). This area is dominated by the hilly topography of the interlobate moraine, which is composed of deep glacial deposits of sand and gravel. Elevations range from $<300 \mathrm{~m}$ along drainage ways to $>450$ $\mathrm{m}$ on hilltops and plateaus. Mean annual temperature is $7.2^{\circ} \mathrm{C}$ and the growing season averages $115 \mathrm{~d}$, extending from early April to late October. Mean annual precipitation of $810 \mathrm{~mm}$ is evenly distributed throughout the year (Albert et al., 1986). The area receives a substantial snowpack that can remain intact through early April. Soils of the study site are sandy, mixed, frigid Typic Haplorthods and have been mapped as Kalkaska sand (Buchanan, 1985).

\section{Overstory and Soil Properties}

In each stand, four 5 by $30 \mathrm{~m}$ plots were located using random azimuths and distances from the areal center of each stand. Plots were oriented lengthwise parallel to slopes. From the center of each plot, overstory basal area was measured using a prism. The species, diameter, and height of each tally tree were recorded. Overstory biomass was estimated for each stand using Biomass, a program that uses species-specific allometric equations developed for the Lake States (Host et al., 1988). The age of several dominant trees in each plot was determined using an increment borer.

Soil bulk density was measured by collecting three 212.4 $\mathrm{cm}^{3}$ cores $(10 \mathrm{~cm}$ deep) per plot. An additional set of samples (three per plot) was collected for determination of $\mathrm{pH}$ and organic C. Soil $\mathrm{pH}$ was measured with a $1: 1$ soil/deionized water paste (McLean, 1982). Organic C was determined by the Walkley-Black method (Nelson and Sommers, 1982).

\section{Soil Nitrogen Dynamics}

Net $\mathbf{N}$ mineralization and nitrification were measured using an in situ buried bag technique (Eno, 1960). A 30-m transect was positioned at the long edge of each plot, and soil samples were collected at $10-\mathrm{m}$ intervals along the transect. On each subsequent sampling date, the transect was moved $0.5 \mathrm{~m}$ toward the plot center. This scheme was derived from a more intensive sampling of the same stands by Zak and Pregitzer (1990). At each sampling point, two soil cores $(5.2-\mathrm{cm}$ diam.) were collected to a depth of $10 \mathrm{~cm}$ from the surface of the mineral soil. Cores consisted of material from the $\mathrm{Oa}, \mathrm{A}$, and $\mathrm{E}$ horizons in each stand. One core was placed undisturbed into a polyethylene bag, sealed, and returned to its original position be-. neath the forest floor. These cores incubated for $4 \mathrm{wk}$ until collection on the following sampling date. The second soil core (initial) was sealed in a polyethylene bag, stored on ice, and transported to the laboratory.

After field collection, both initial and incubated cores were stored at $4{ }^{\circ} \mathrm{C}$ and were processed within 24 to $48 \mathrm{~h}$. Roots and material $>2 \mathrm{~mm}$ were removed by hand and the contents were thoroughly mixed while still within the polyethylene bag. A $10-\mathrm{g}$ subsample from each bag was oven dried for $24 \mathrm{~h}$ at $105^{\circ} \mathrm{C}$ to determine dry weight. A second field-moist $10-\mathrm{g}$ subsample was extracted with $20 \mathrm{~mL} 2 M \mathrm{KCl}$. Filtrates were analyzed for $\mathrm{NH}_{4}^{+}-\mathrm{N}$ and $\mathrm{NO}_{3}^{-}-\mathrm{N}$ using automated colorimetry (Alpkem RFA 300, Alpkem Corp., Wilsonville, OR).

Net $\mathbf{N}$ mineralization was calculated as the $\mathrm{NH}_{4}^{+}-\mathrm{N}$ and $\mathrm{NO}_{3}^{-}-\mathrm{N}$ in the incubated samples in excess of initial concentrations. Net nitrification was calculated from the increase of $\mathrm{NO}_{3}^{-}-\mathrm{N}$. Pools and rates were expressed on an areal basis using bulk densities. Soil sampling began on 26 May 1990 and continued at 4-wk intervals through November 1990. Sampling resumed the following spring (May 1991) when enough snow had cleared to allow access to the sites.

\section{Microbial Biomass Carbon and Nitrogen}

Microbial biomass $\mathrm{C}$ and $\mathrm{N}$ were estimated in incubated soil using the chloroform fumigation-incubation assay (Voroney and Paul, 1984). A 20-g subsample from each incubated soil sample was fumigated for $18 \mathrm{~h}$ with ethanol-free chloroform in a vacuum desiccator. A second $20-\mathrm{g}$ subsample was simultaneously incubated in a moist desiccator (no chloroform) to act as a control. After repeated vacuuming and aeration (eight volumes) to eliminate residual chloroform, each fumigated sample was inoculated with $0.5 \mathrm{~g}$ of soil from the paired nonfumigated sample. Fumigated and nonfumigated samples were incubated for $10 \mathrm{~d}$ at $25^{\circ} \mathrm{C}$ in 1-L Mason jars equipped with septa. Headspace gas samples $(0.4 \mathrm{~mL})$ were analyzed for $\mathrm{CO}_{2}$ using a Tracor 540 gas chromatograph (Tremetrics Corp., Austin, TX) equipped with a Porapak $Q$ column (50/80 mesh, Waters Chromotography Div., Millipore Corp., Milford, MA) and a thermal conductivity detector. Soils were extracted with $2 M \mathrm{KCl}$, and the filtrates were analyzed for $\mathrm{NH}_{4}^{+}-\mathrm{N}$ and $\mathrm{NO}_{3}^{-}-\mathrm{N}$ by automated colorimetry. Microbial $\mathrm{C}$ was calculated by dividing the flush of $\mathrm{CO}_{2}-\mathrm{C}$ from fumigated samples by 0.41 (Voroney and Paul, 1984). Microbial N was calculated by dividing the flush of $\mathrm{N}$ (fumigated minus control) by a correction factor $\left(k_{n}\right)$, calculated for each sample using the equation of Voroney and Paul (1984); $k_{n}=-0.014\left(\mathrm{C}_{\mathrm{f}}\left(\mathrm{N}_{\mathrm{f}}\right)\right.$ +0.39 , where $C_{f}$ and $N_{f}$ are the flushes of $C$ and $N$, respectively, from fumigated samples.

\section{Statistical Analyses}

An ANOVA was used to compare temporal changes in net $\mathrm{N}$ mineralization, nitrification, and microbial biomass content between ecosystems and stands. Plot means were analyzed using a balanced three-factor partially crossed and partially nested ANOVA (Wilkinson, 1990). Date and ecosystem were fixed factors and stand was a random factor. Stands were nested within ecosystems, which were crossed with dates. Stand and ecosystem means were compared using Fisher's LSD procedure. Linear regression analysis was used to test relationships between microbial biomass $(C$ and $N$ ) and net $N$ mineralization. Annual rates of net $\mathrm{N}$ mineralization and nitrification were compared with those measured by Zak and Pregitzer (1990) using a $t$-test for independent observations. In addition, we also compared ( $t$-test) monthly temperature and precipitation between studies (1984-1985 vs. 1990-1991). Climatic data for both years were obtained from a weather station operated by the USDA Forest Service; distances to individual stands ranged from 5 to $28 \mathrm{~km}$. All statistical results were accepted as significant at $P=0.05$. 
Table 1. Overstory and soil properties of two hardwood forest ecosystems in northern Lower Michigan. Values represent stand means with standard deviations in parentheses.

\begin{tabular}{|c|c|c|c|c|}
\hline & \multicolumn{2}{|c|}{$\begin{array}{l}\text { Sugar maple-red oak/ } \\
\text { Maianthemum ecosystem }\end{array}$} & \multicolumn{2}{|c|}{$\begin{array}{c}\text { Sugar maple-basswood/ } \\
\text { Osmorhiza ecosystem }\end{array}$} \\
\hline & Stand 1 & Stand 2 & Stand 1 & Stand 2 \\
\hline \multicolumn{5}{|c|}{ Overstory } \\
\hline $\begin{array}{l}\text { Age, yr } \\
\text { Stems ha-1 }\end{array}$ & $\begin{array}{r}66(5.1) \\
1017(159)\end{array}$ & $\begin{array}{c}68(7.6) \\
883(223)\end{array}$ & $\begin{aligned} 76 & (3.2) \\
467 & (82)\end{aligned}$ & $\begin{aligned} 71(8.4) \\
817(29)\end{aligned}$ \\
\hline$m^{2} \mathbf{h a}^{-1}$ & $31(6.0)$ & $35(11.0)$ & $37(15.0)$ & $29(8.0)$ \\
\hline $\begin{array}{l}\text { Biomass, } \\
\text { t ha-1 }\end{array}$ & $255(9.9)$ & $265(97.6)$ & $284(115.1)$ & $201(43.1)$ \\
\hline \multicolumn{5}{|c|}{ Soil 0 to $10 \mathrm{~cm}$} \\
\hline $\begin{array}{l}\text { Bulk density, } \\
\mathbf{M g ~ m}^{-3} \\
\text { Organic C }\end{array}$ & $1.2(0.09)$ & $1.2(0.17)$ & $0.9(0.16)$ & $1.0(0.19)$ \\
\hline pH & $\begin{array}{l}1.0(0.00) \\
4.8(0.06)\end{array}$ & $\begin{array}{l}1.5(0.12) \\
4.4(0.00)\end{array}$ & $\begin{array}{l}2.0(0.11) \\
6.5(0.05)\end{array}$ & $\begin{array}{l}3.2(0.23) \\
6.0(0.04)\end{array}$ \\
\hline
\end{tabular}

\section{RESULTS \\ Overstory and Soil Properties}

Age, basal area, and biomass were similar among ecosystems and among stands nested within them. Soil bulk density was also similar in both ecosystems. Soil of the sugar maple-basswood/Osmorhiza ecosystem had a more neutral $\mathrm{pH}$ and twice the organic $\mathrm{C}$ content than that of the sugar maple-red oak/Maianthemum ecosystem (Table 1).

\section{Nitrogen Mineralization and Nitrification}

Mean daily rates of net $\mathrm{N}$ mineralization did not differ significantly between the two ecosystems through the growing season (Fig. 1a). Both exhibited temporal variability in net $\mathrm{N}$ mineralization with highest rates occurring midsummer and late fall. Throughout the year, rates of net nitrification were significantly greater in the sugar maple-basswood/Osmorhiza ecosystem. In this ecosystem, the seasonal pattern of net nitrification closely paralleled the seasonal pattern of net $\mathrm{N}$ mineralization; the two rates were approximately equivalent for each 4-wk incubation interval (compare Fig. 1a and 1b). Rates of net nitrification in the sugar maple-red oak/Maianthemum ecosystem were consistently low and displayed less temporal variation; highest rates occurred simultaneously with peaks in mineralization rates. Stands differed significantly in $\mathrm{N}$ mineralization within the sugar maple-red oak/Maianthemum ecosystem in April 1991 and within the sugar maple-basswood/Osmorhiza ecosystem in September and November 1990 (Fig. 2a). Stands within each ecosystem did not differ significantly in nitrification on any sampling date (Fig. 2b).

The two ecosystems had similar rates of annual net $\mathbf{N}$ mineralization, but differed significantly in mean annual nitrification rate (Table 2). In the sugar maple-basswood/Osmorhiza ecosystem, annual net nitrification was equivalent to annual mineral $\mathbf{N}$ production. In the sugar maple-red oak/Maianthemum ecosystem, however, annual net nitrification was $42 \%$ of annual mineral $\mathrm{N}$ production. Relationships between mean annual mineralization and nitrification at the stand level were identical to those at the ecosystem level. Mean annual

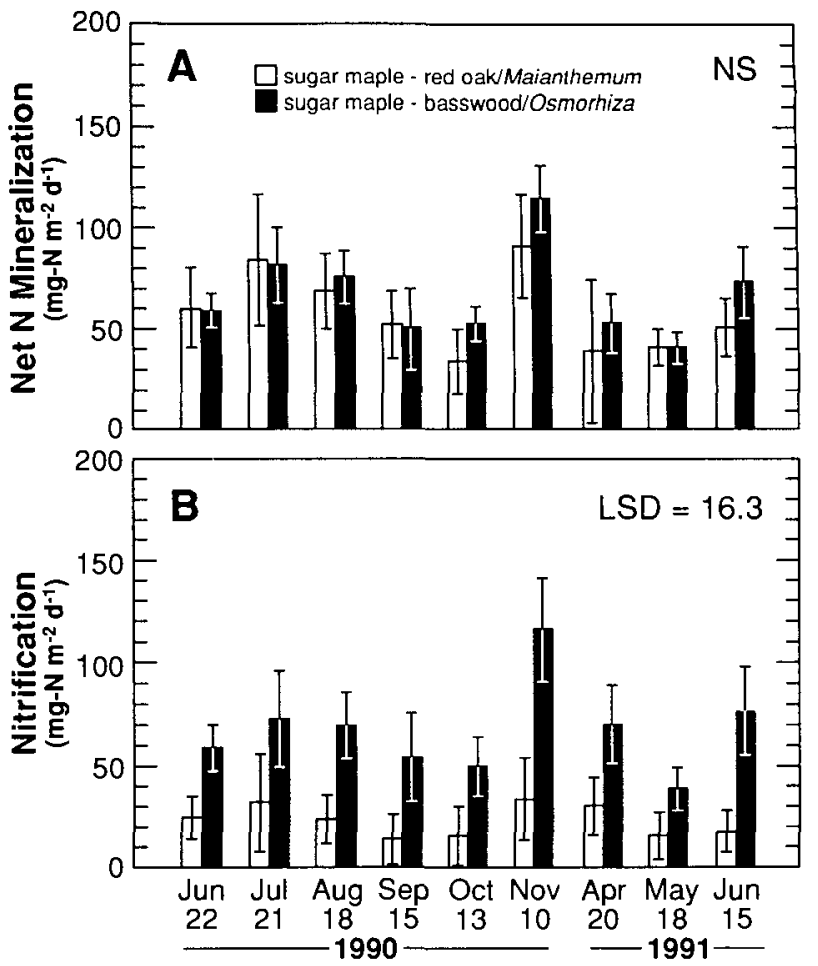

Fig. 1. Mean daily rates of (A) net $\mathbf{N}$ mineralization and (B) nitrification in two hardwood forest ecosystems in northern Lower Michigan. Values are ecosystem means $(n=32)$ with standard errors.

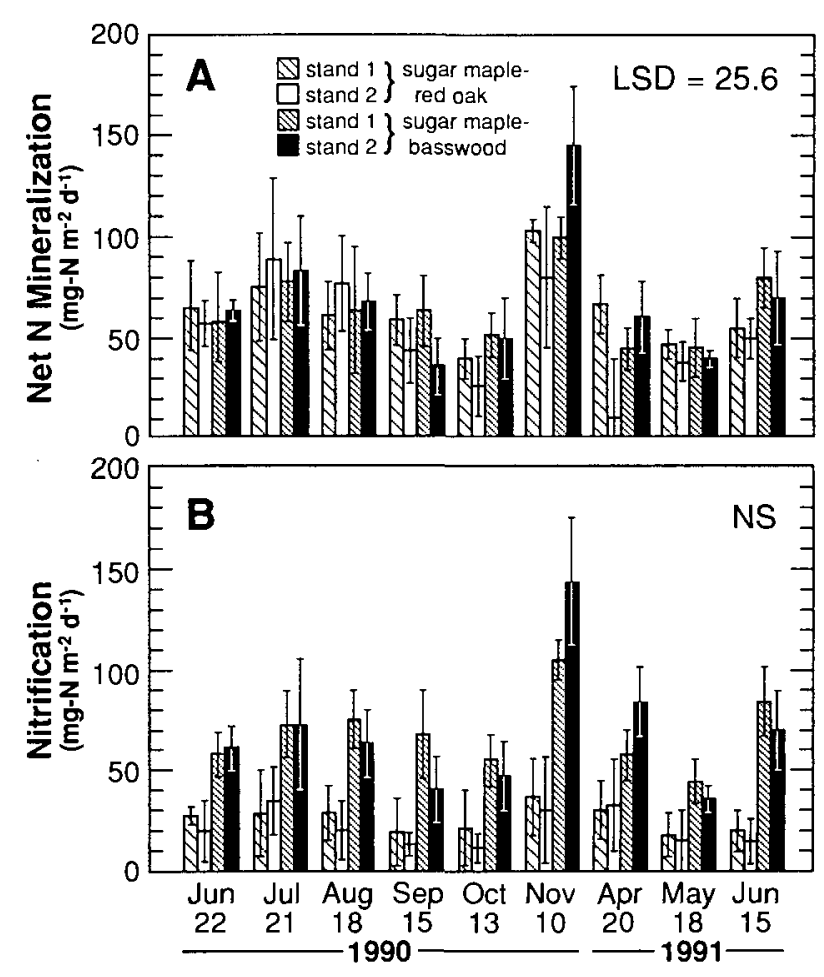

Fig. 2. Mean daily rates of (A) net $\mathbf{N}$ mineralization and (B) nitrification in individual stands of two hardwood forest ecosystems in northern Lower Michigan. Values are stand means $(n=16)$ with standard errors. 
Table 2. Mean annual rates of net $\mathbf{N}$ mineralization and nitrification and mean pools of microbial $C$ and $N$ for two forest ecosystems in northern Lower Michigan during the 1990 growing season. Values are ecosystem means with standard deviations in parentheses.

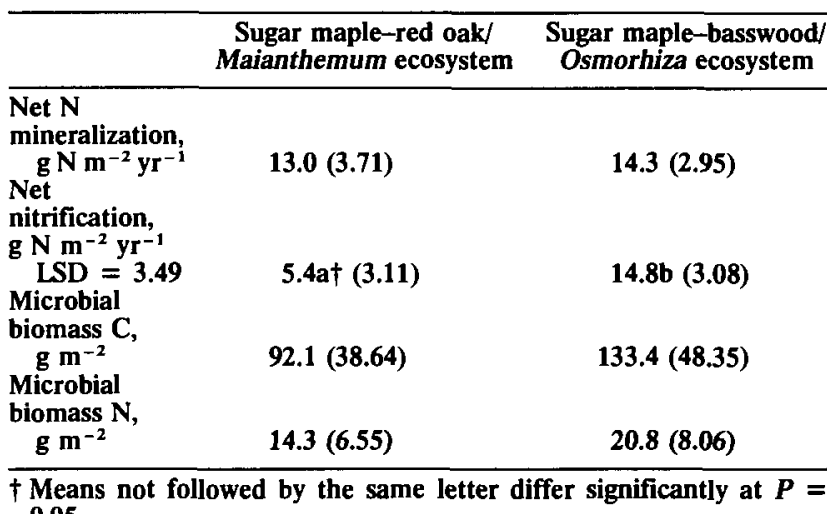
0.05 .

rates of $\mathbf{N}$ mineralization and nitrification at the stand level were not significantly different $(t$-test) from those measured by Zak and Pregitzer (1990) during 1984-1985. In addition, monthly temperatures and precipitation volumes during our study did not significantly differ from those in 1984-1985.

\section{Microbial Biomass Carbon and Nitrogen}

Microbial biomass $\mathrm{C}$ and $\mathrm{N}$ did not differ significantly between the two ecosystems on any sampling date (Fig. 3 ). Although mean annual microbial biomass $\mathrm{C}$ and $\mathrm{N}$ were greater in the sugar maple-basswood/Osmorhiza ecosystem than in the sugar maple-red oak/Maianthemum ecosystem, these differences were not statistically significant (Table 2). The $\mathrm{C} / \mathrm{N}$ ratio of the microbial biomass was 6.4 for both ecosystems. Neither ecosystem displayed significant temporal change in microbial $\mathrm{C}$ or $\mathrm{N}$ pools (Fig. 3). Microbial $\mathrm{C}$ and $\mathrm{N}$ pools in Stand 2 of the sugar maple-basswood/Osmorhiza ecosystem were $40 \%$ greater than pools within all other stands. During the year, the smallest pool measured in this stand was greater than or equal to the largest pools in other stands (Fig. 4). This stand was also distinguished by its seasonal variability: from early to late summer microbial $\mathrm{C}$ and $\mathrm{N}$ pools decreased, then nearly doubled by late Fall (Fig. 4).

Neither microbial biomass ( $\mathrm{C}$ or $\mathrm{N}$ ) nor the change in microbial biomass between sampling dates were significantly correlated with net $\mathrm{N}$ mineralization at either the ecosystem or stand level. Microbial biomass $\mathrm{C}$ (averaged across dates) was significantly correlated with soil organic $\mathrm{C}$ on a stand basis $(n=4): \mathrm{BC}=0.039(\mathrm{OC})+$ $36.10\left(r^{2}=0.994, \mathrm{MSE}=9.84, P=0.003\right)$, where $\mathrm{BC}=$ microbial biomass $\mathrm{C}\left(\mathrm{g} \mathrm{C} \mathrm{m}^{-2}\right)$ and $\mathrm{OC}=$ organic $\mathrm{C}\left(\mathrm{g} \mathrm{C} \mathrm{m}^{-2}\right)$.

\section{DISCUSSION}

\section{Soil Microbial Biomass and Nitrogen Dynamics}

The $\mathbf{N}$ dynamics of terrestrial ecosystems are fundamentally controlled through the population dynamics of soil microorganisms. As such, microbial biomass represents a significant source of available $\mathrm{N}$, the amount
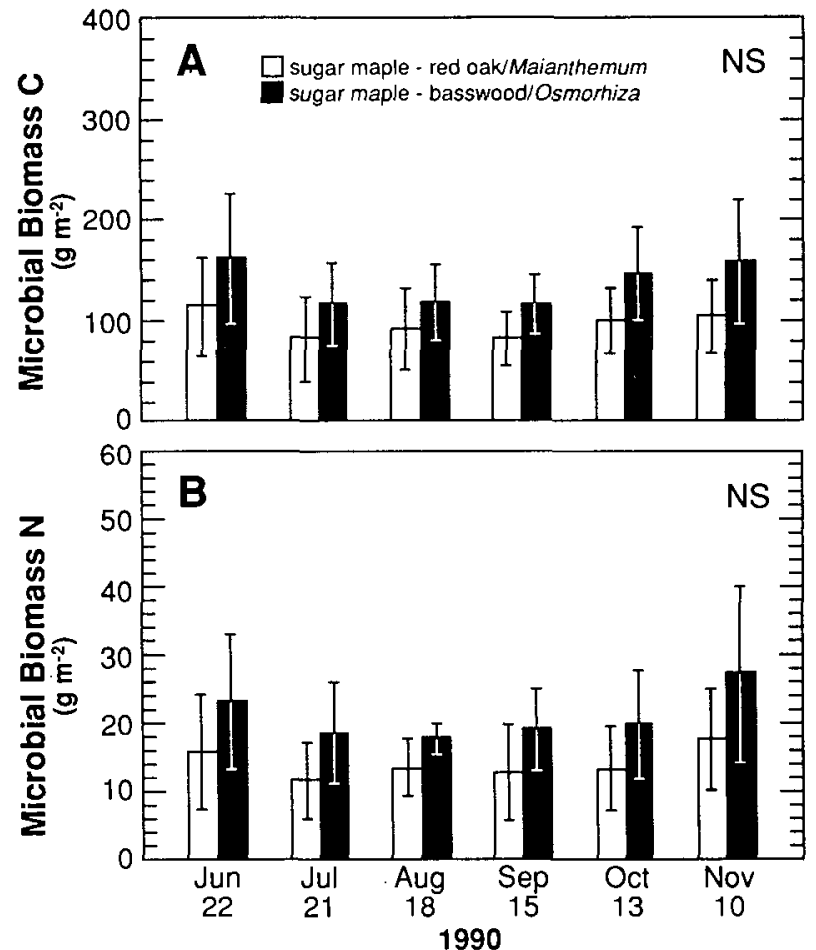

Fig. 3. Seasonal pattern of soil microbial biomass $(\overline{\mathbf{A}}) \overline{\mathbf{C}}$ and (B) $\mathbf{N}$ for two forest ecosystems in northem Lower Michigan. Values are ecosystem means $(n=32)$ with standard errors.

of which is controlled through the balance of gross rates of $\mathrm{N}$ immobilization and mineralization. These processes
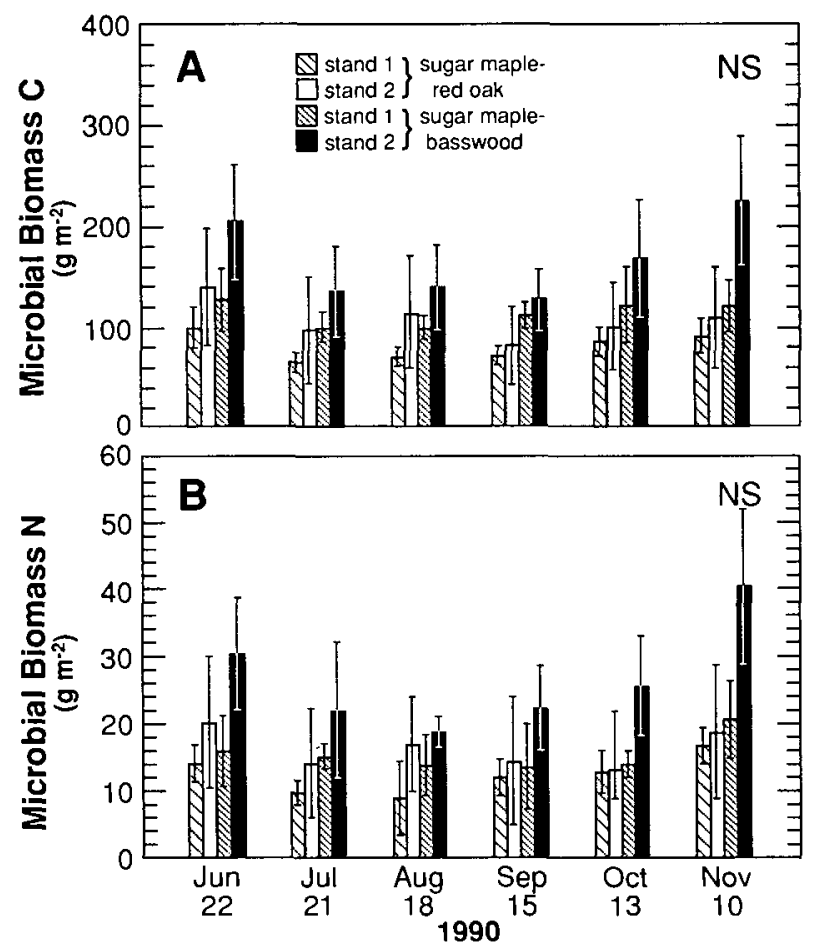

Fig. 4. Seasonal pattern of soil microbial biomass (A) $C$ and (B) $\mathbf{N}$ for individual stands within two forest ecosystems in northern Lower Michigan. Values are stand means $(n=$ 16) with standard errors. 
are influenced by the flux of labile $\mathrm{C}$ from the aboveand belowground production of plant litter. Therefore, microbial biomass should vary with seasonal changes in factors controlling microbial growth (e.g., C availability) and this should, in turn, influence rates of net $N$ mineralization. In the northern hardwood ecosystems we studied, however, microbial biomass pools displayed small seasonal fluctuations and were not significantly correlated with rates of net $\mathbf{N}$ mineralization. This pattern suggests that the pool of microbial biomass remains relatively constant, while turnover of that pool varies with time. In other words, net $\mathbf{N}$ mineralization is probably driven by the turnover of microbial biomass rather than by changes in the size of the microbial pool.

In 1990 for example, the fall peak (between 13 October and 10 November) in net $\mathrm{N}$ mineralization followed a period of increased $\mathrm{C}$ availability. In northern hardwood ecosystems, $>80 \%$ of annual aboveground litter and about $20 \%$ of annual belowground litter occur at this time (Pregitzer and Burton, 1991; Hendrick and Pregitzer, 1993). During this period, net $\mathrm{N}$ mineralized represented $13 \%$ of microbial $\mathrm{N}$, but the observed $38 \%$ increase in microbial $\mathrm{N}$ was not significant. Patra et al. (1990) argued that seasonal fluctuations in the microbial biomass pool are dampened due to a relatively even distribution of litter inputs with time. Hendrick and Pregitzer (1993) found that, although peaks in fine root mortality for a northern hardwood ecosystem occurred in spring and fall, $30 \%$ of annual fine root turnover occurred from June through September. This observation, in conjunction with small seasonal changes in microbial biomass, supports the contention of Patra et al. (1990).

Microbial biomass appeared to decrease during the summer and increase in the fall (Fig. 4). A high degree of within-ecosystem variability may have led to the lack of significance of these temporal changes. Alternatively, the lack of significant variation in microbial biomass may have resulted from our sampling design. For example, a 28-d sampling interval could be too long to detect shortterm variations. Clarholm and Rosswall (1980) found that daily variation in microbial biomass could exceed longer term (e.g., monthly) variation. In addition, because biomass was measured within our buried bags, measurements may not reflect actual dynamics of soil microbial populations. Effects of the buried bag, such as disruption of root growth, input of organic $\mathrm{C}$ through the death of fine roots, and the interruption of alternating moist and dry conditions, could influence microbial biomass differentially through the growing season. Some of these alternatives could be evaluated by studying fresh (i.e., unincubated) soil samples. Additional insight into the role of microbial dynamics in $\mathrm{N}$ cycling also could be gained by measuring $\mathrm{N}$ immobilization, microbial respiration, and organic $\mathrm{C}$, in addition to microbial biomass and net $\mathrm{N}$ mineralization.

Estimates of microbial $\mathrm{C}$ and $\mathrm{N}$ for these northern hardwood ecosystems fall within the range of values summarized for other forest ecosystems (50-218 g C $\mathrm{m}^{-2}, 13-22 \mathrm{~g} \mathrm{~N} \mathrm{~m}^{-2}$; Smith and Paul, 1990). However, the rates of net $\mathrm{N}$ mineralization we measured generally exceeded those reported for other Lake States forests (2$12 \mathrm{~g} \mathrm{~N} \mathrm{~m}^{-2} \mathrm{yr}^{-1}$; Nadelhoffer et al., 1983; Pastor et al., 1984; Plymale et al., 1987; Zak et al., 1991; Zak and Grigal, 1991). Interestingly, the amount of $\mathrm{N}$ annually released via net $\mathrm{N}$ mineralization was equivalent to that contained in microbial biomass (13-14 $\mathrm{g} \mathrm{N} \mathrm{m}^{-2}$ ). Furthermore, this quantity was comparable to $\mathrm{N}$ entering soil from above- and belowground litter sources $(11.3 \mathrm{~g}$ $\mathrm{N} \mathrm{m}^{-2} \mathrm{yr}^{-1}$; Pregitzer and Burton, 1991; Hendrick and Pregitzer, 1993). These data suggest that relatively large quantities of $\mathrm{N}$ are cycled annually, and that the turnover of microbial biomass plays a major role in regulating $\mathbf{N}$ availability within these ecosystems. Moreover, the relationship we found between soil organic $\mathrm{C}$ and microbial biomass suggests that long-term patterns of $C$ additions influence the microbial biomass content of soil to a greater extent than seasonal variation in $\mathrm{C}$ inputs.

\section{Seasonal and Year-to-Year Variation}

Reed et al. (1992) reported a high degree of year-toyear variability in overstory production in northern hardwood ecosystems similar to those we studied. Pregitzer and Burton (1991) also have found significant withinsite year-to-year variability in litterfall $\mathrm{N}$; fluxes doubled in years of peak seed production. They reported substantial litterfall $\mathbf{N}$ in the spring of years when sugar maple flowers abundantly. Such annual variation in overstory production and litterfall should influence substrate availability for soil heterotrophs, and therefore, rates of net $\mathbf{N}$ mineralization and nitrification. Combined with variation in temperature and precipitation, the aforementioned studies suggest that annual rates of net $\mathrm{N}$ mineralization could exhibit substantial year-to-year variation.

Recent studies of temporal patterns of $\mathrm{N}$ mineralization in forest ecosystems have demonstrated the importance of repeated sampling during the growing season (Pastor et al., 1984). Due to seasonal variability in $\mathrm{N}$ cycling rates, one or a few measurements are inadequate to characterize $\mathrm{N}$ turnover rates of an ecosystem. But given that sequential sampling was employed to calculate annual estimates of net $\mathrm{N}$ mineralization and nitrification, are these estimates meaningful in the face of yearto-year variation in factors controlling these rates, such as temperature and precipitation? A comparison of mean annual rates of net $\mathbf{N}$ mineralization and nitrification estimated for 1990-1991 to those estimated by Zak and Pregitzer (1990) for 1984-1985 suggest that annual estimates provide repeatable measures of $\mathbf{N}$ cycling rates in northern hardwood ecosystems. Despite small differences in the seasonal patterns observed in each study, both mean annual estimates, as well as variation in $\mathrm{N}$ cycling rates, were similar. For example, mean annual nitrification had equivalent standard deviation among stands in both studies (SD $=5.93 \mathrm{~g} \mathrm{~N} \mathrm{~m}^{-2} \mathrm{yr}^{-1}$ for 1984-1985 and 5.48 $\mathrm{g} \mathrm{N} \mathrm{m}^{-2} \mathrm{yr}^{-1}$ for 1990-1991).

The close agreement between estimates of net $\mathrm{N}$ mineralization could have occurred through two different mechanisms. If the in situ incubation technique was sensitive to seasonal changes in controlling factors, then similar patterns of temperature, precipitation, and substrate input between years should produce similar temporal patterns of net $\mathrm{N}$ mineralization. Alternatively, the in situ incubation technique could be relatively insensitive to such differences, providing similar estimates even though temperature and precipitation differ between years. However, monthly temperatures and precipitation did not 
differ significantly between our study and that of Zak and Pregitzer (1990). Our results indicate that this procedure provides repeatable measures of annual net $\mathrm{N}$ mineralization and nitrification in climatically similar years.

\section{SUMMARY}

Microbial biomass $\mathrm{C}$ did not vary significantly through the growing season and, consequently, was not related to changes in rates of net $\mathrm{N}$ mineralization in the northern hardwood ecosystems we studied. Therefore, $\mathrm{N}$ availability may be controlled to a greater extent by the turnover of microbial biomass rather by than changes in the size of the microbial biomass pool. The dynamics of microbial turnover could further be studied through measurement of gross rates of $\mathrm{N}$ mineralization and immobilization using ${ }^{15} \mathrm{~N}$-enrichment techniques. In addition, our results demonstrate the importance of quantifying annual rates of $\mathrm{N}$ turnover for the purposes of comparative ecosystem study. The in situ incubation technique yields consistent estimates of mean annual rates of net $\mathrm{N}$ mineralization and nitrification in different years with similar patterns of temperature and precipitation. Although seasonal patterns of net $\mathrm{N}$ mineralization may differ, mean annual rates displayed a small amount of variation from year to year.

\section{ACKNOWLEDGMENTS}

This manuscript is based on portions of a thesis submitted by the senior author in partial fulfillment of the requirements of the Master of Science degree in the School of Natural Resources and Environment, University of Michigan. Our study was supported by funds from the McIntire-Stennis Cooperative Forestry Act (P.L. 87-788). We are grateful for the assistance of Matthew Sands (USDA Forest Service, Manistee National Forest), Amy Merrill, David Toland, and Diana Randlett. Burton Barnes and Neil MacDonald provided critical input on an earlier draft of the manuscript; we sincerely thank them.

\section{REFERENCES}

Albert; D.A., S.R. Denton, and B.V. Barnes. 1986. Regional landscape ecosystems of Michigan. School of Nat. Resources, Univ. of Michigan, Ann Arbor.

Barnes, B.V., K.S. Pregitzer, T.A. Spies, and V.H. Spooner. 1982. Ecological forest site classification. J. For. 80:493-498.

Buchanan, D.E. 1985. Soil survey of Lake and Wexford counties, Michigan. USDA-SCS. U.S. Gov. Print. Office, Washington, DC.

Clarholm, M., and T. Rosswall. 1980. Biomass and turnover of bacteria in a forest soil and a peat. Soil Biol. Biochem. 12:49 57.

Eno, C.F. 1960. Nitrate production in the field by incubating soil in polyethylene bags. Soil Sci. Soc. Am. Proc. 24:227-279.

Groffman, P.M., and J.M. Tiedje. 1989. Denitrification in north temperate forest soils: Spatial and temporal patterns at the landscape and seasonal scales. Soil Biol. Biochem. 21:613-620.

Hendrick, R.L., and K.S. Pregitzer. 1993. The dynamics of fine root length, biomass, and nitrogen content in two northern hardwood ecosystems. Can. J. For. Res. (in press).

Host, G.E., S. Westin, W. Cole, and K.S. Pregitzer. 1988. The microcomputer software series 5: BIOMASS - An interactive program to calculate above-ground biomass of common tree species of the Lake States forests. U.S. For. Serv. Gen. Tech. Rep. NC-127. North Central Exp. Stn., St. Paul, MN.

McLean, E.O. 1982. Soil $\mathrm{pH}$ and lime requirement. p. 199-223. In A.L. Page et al. (ed.) Methods of soil analysis. Part 2. 2nd ed. Agron. Monogr. 9. ASA and SSSA, Madison, WI.

Nadelhoffer, N.J., J.D. Aber, and J.M. Melillo. 1983. Leaf-litter and soil organic matter dynamics along a nitrogen-availability gradient in southern Wisconsin. Can. J. For. Res. 13:12-21.

Nelson, D.W., and L.E. Sommers. 1982. Total carbon, organic carbon, and organic matter. p. 539-580. In A.L. Page, et al. (ed.) Methods of soil analysis. Part 2. 2nd ed. Agron. Monogr. 9. ASA and SSSA, Madison, WI.

Pastor, J., J.D. Aber, C.A. McClaugherty, and J.M. Melillo. 1984. Aboveground production and $\mathbf{N}$ and $\mathrm{P}$ cycling along a nitrogen mineralization gradient on Blackhawk Island, Wisconsin. Ecology 65:256-268.

Patra, D.D., P.C. Brookes, K. Coleman, and D.S. Jenkinson. 1990. Seasonal changes of soil microbial biomass in an arable and a grassland soil which have been under uniform management for many years. Soil Biol. Biochem. 22:739-742.

Plymale, A.E., R.E.J. Boerner, and T.J. Logan. 1987. Relative nitrogen mineralization and nitrification in soil of two contrasting hardwood forests: Effects of site microclimate and initial soil chemistry. For. Ecol. Manage. 21:21-36.

Pregitzer, K.S and B.V. Barnes. 1984. Classification and comparison of upland hardwood ecosystems of the Cyrus McCormick Experimental Forest, Upper Michigan. Can. J. For. Res. 14:362-375

Pregitzer, K.S., and A.J. Burton. 1991. Sugar maple seed production and nitrogen in litterfall. Can. J. For. Res. 21:11481153.

Reed, D.D., E.A. Jones, H.O. Liechty, G.D. Mroz, and M.J. Jurgensen. 1992. Impacts of annual weather conditions on forest productivity: A case study involving four North American deciduous tree species. Int. J. Biometeorol. 36:51-57.

Singh, J.S., A.S. Raghubanshi, R.S. Singh, and S.C. Srivastava. 1989. Microbial biomass acts as a source of plant nutrients in dry tropical forest and savanna. Nature (London) 338:499-500.

Smith, J.L., and E.A. Paul. 1990. The significance of soil microbial biomass estimations. p. 357-396. In J. Bollag and G. Stotzky (ed.) Soil biochemistry. Vol. 6. Marcel Dekker, New York.

Srivastava, S.C. 1992. Microbial C, N, and P in dry tropical soils: Seasonal changes and influence of soil moisture. Soil Biol. Biochem. 24:711-714.

Voroney, R.P., and E.A. Paul. 1984. Determination of $k_{\mathrm{c}}$ and $k_{\mathrm{n}}$ in situ for calibration $f$ the chloroform fumigation-incubation method. Soil Biol. Biochem. 16:9-14.

Wilkinson, L. 1990. SYSTAT: The system for statistics. SYSTAT, Evanston, IL.

Zak, D.R., and D.F. Grigal. 1991. Nitrogen mineralization, nitrification and denirification in upland and wetland ecosystems. Oecologia 88:189-196.

Zak, D.R., A.B. Hairston, and D.F. Grigal. 1991. Topographic influences on nitrogen cycling within an upland pin oak ecosystem. For. Sci. 37:45-53.

Zak, D.R., and K.S. Pregitzer. 1990. Spatial and temporal variability in nitrogen cycling in northern Lower Michigan. For. Sci. 36:367-380. 